\title{
Effects of fishery protection on biometry and genetic structure of two target sea cucumber species from the Mediterranean Sea
}

\author{
Mercedes González-Wangüemert • Sara Valente • \\ Mehmet Aydin
}

Received: 20 June 2014/Revised: 1 August 2014/ Accepted: 2 August 2014/Published online: 14 August 2014

(C) Springer International Publishing Switzerland 2014

\begin{abstract}
Sea cucumber fisheries are now occurring in most of the tropical areas of the world, having expanded from its origin in the central Indo-Pacific. Due to the overexploitation of these resources and the increasing demand from Asian countries, new target species from Mediterranean Sea and northeastern Atlantic Ocean are being caught. The fishery effects on biometry and genetic structure of two target species (Holothuria polii and H. tubulosa) from Turkey, were assessed. The heaviest and largest individuals of $H$. polii were found into the non-fishery area of Kusadasi, also showing the highest genetic diversity. Similar pattern was detected in $H$. tubulosa, but only the weight was significantly higher in the protected area. However, the observed differences on the fishery effects between species, could be explained considering the different percentage of catches $(80 \%$ for $H$. polii and $20 \%$ for H. tubulosa).
\end{abstract}

Handling editor: Vasilis Valavanis

M. González-Wangüemert $(\bowtie) \cdot S$. Valente

Centro de Ciências do Mar (CCMAR), CIMAR-

Laboratório Associado, Universidade do Algarve,

Gambelas, 8005-139 Faro, Portugal

e-mail: mwanguemert@ualg.pt

M. Aydin

Faculty of Marine Sciences, Ordu University,

52400 Fatsa, Ordu, Turkey
Keywords Fishery effects · Holothurians · Eastern Mediterranean Sea $\cdot$ Marine protected areas

\section{Introduction}

Most of global finfish catches have declined or remained stable since the early 1990s, whereas global invertebrate catches kept increasing (Anderson et al., 2011). Some of those catches started hundreds years ago (i.e., sea cucumbers in China, 1,000 years ago; Conand, 1989, 1990; Lovatelli et al., 2004; ToralGranda et al., 2008; Purcell et al., 2013), but most of them have quickly expanded over the last decades. Invertebrate fisheries are typically less assessed and monitored, and often unregulated, which hamper their sustainability.

Sea cucumber fisheries are now occurring worldwide, having expanded from its origin in the central Indo-Pacific where they have been active since 1700s (Conand, 1990; Lovatelli et al., 2004; Toral-Granda et al., 2008; Eriksson et al., 2012a; Purcell et al., 2013; Purcell, 2014). Particularly, tropical fisheries contribute most to global captures, involving a multi-species complex. Those fisheries are often small-scale, typified by fishers gleaning at low tide, or free-diving on shallow reefs (Conand, 2004, 2008; Eriksson et al., 2012a). Sea cucumbers are sometimes eaten locally, although most of the captures are boiled, dried and exported to the distribution hubs in Asia mainly as 
"bêche-de-mer" (Conand \& Byrne, 1993; Conand, 2008; Purcell, 2014). In contrast, most of temperate fisheries are rather industrialized, single-species and involve large boats with sophisticated gear to harvest from deep waters or with hookah diving systems (Aydin, 2008; Hamel \& Mercier, 2008; GonzálezWangüemert et al., 2014).

Annual total global catch of sea cucumbers in form of live animals is around 100,000 tonnes (Purcell, 2010), resulting on overfishing in many countries (Conand, 2004, 2008). The life-history traits of holothurians make them particularly vulnerable to overexploitation due to late age at maturity, reproduction on an infrequent annual basis (broadcast spawners), density-dependent reproductive success, low or infrequent recruitment, high longevity and slow growth (Uthicke et al., 2004).

Overfishing in tropical areas together with the increasing demand from Asian countries has forced the catch of new target species from Mediterranean Sea and Northeastern Atlantic Ocean (Aydin, 2008; González-Wangüemert \& Borrero-Pérez, 2012; González-Wangüemert et al., 2013a, b). Holothuria polii, H. tubulosa, H. mammata and Parastichopus regalis are target species on Turkish fisheries, despite of scarce information on their ecology, reproduction, feeding and biology (Coulon \& Jangoux, 1993; Mezali et al., 2006; Kazanidis et al., 2010).

Turkish sea cucumber fisheries started in 1996 and reached around 600 tonnes in 2011; H. polii represented the $80 \%$ of these catches (González-Wangüemert et al., 2014). They are mainly exported to Asian countries as frozen, dried, and salted products (Aydin, 2008; Aydin et al., 2011). Hookah diving vessels are the most commonly used to catch sea cucumbers through underwater breathing devices. Such practices have been described as a "human and environmental disaster', mainly due to the high risk of personnel accidents and indiscriminate harvesting (Maillaud, 1999; Ruffez, 2008; Eriksson et al., 2012a). Despite that scuba diving for sea cucumbers is being carried out commonly in the Western Indian Ocean and nowadays also in the Eastern Mediterranean Sea (Turkey), only one systematic study has been done focusing on this category of mobile fishing in Zanzibar (Eriksson et al., 2012a). Therefore, sea cucumber fisheries in Turkey is a matter of concern, considering those three factors: (1) new target species are being caught without any previous data about their ecology, growth, reproduction and feeding; (2) those species occur in sympatry, showing similar external morphology, and thereby complicating their identification; (3) fishery practices are extremely dangerous for the fisherman, also with unknown consequences on the population dynamics of the species and the ecosystems. In this work, we address those gaps of knowledge by studying the genetic and biological effects of the Turkish hookah diving fishery on two sea cucumber species (Holothuria polii and H. tubulosa), with these specific aims: (i) to evaluate the conservation status of the two target species by analyzing and comparing biological parameters of stocks (size distribution and weight classes) in a traditional fishery area (Ayvalik) and a non-fishery area (Kusadasi) and (ii) to establish the relationships between observed genetic diversity patterns with the effects of fishery selection.

\section{Methods}

Sampling

Sea cucumber captures in Turkey are authorized by the General Directorate of Fisheries and Aquaculture (GDAR) and by the Ministry of Food, Agriculture and Livestock (MoFAl). In 2002, MoFAL established a closed fishery season for sea cucumber during the summer (1st August-15th September) in the Northern Turkish coasts. This closed fishery season was maintained until 2007, when MoFAL published a new regulation allowing hand catch of sea cucumbers (using diving equipment) from the 15th of September to the 15th of July in the Northern Aegean Sea (Turkey). Finally, in September 2012, MoFAL restricted the sea cucumber fishery in the Northern Aegean Sea and opened this activity to the Southern region, establishing a closed fishery season from June to October (González-Wangüemert et al., 2014). Therefore, no more populations without fishery impact can be sampled in this area.

The study focused on the Eastern Aegean Sea during the fishing season in March 2012 (Fig. 1). The sea cucumber sampling was carried out using the facilities offered by hookah diving vessels which are commercially operating in Ayvalik (fishery area) and using experimental fisheries in Kusadasi (non-fishery area). The samplings in Kusadasi were carried out 
Fig. 1 Map showing the sampling localities in Turkish coasts
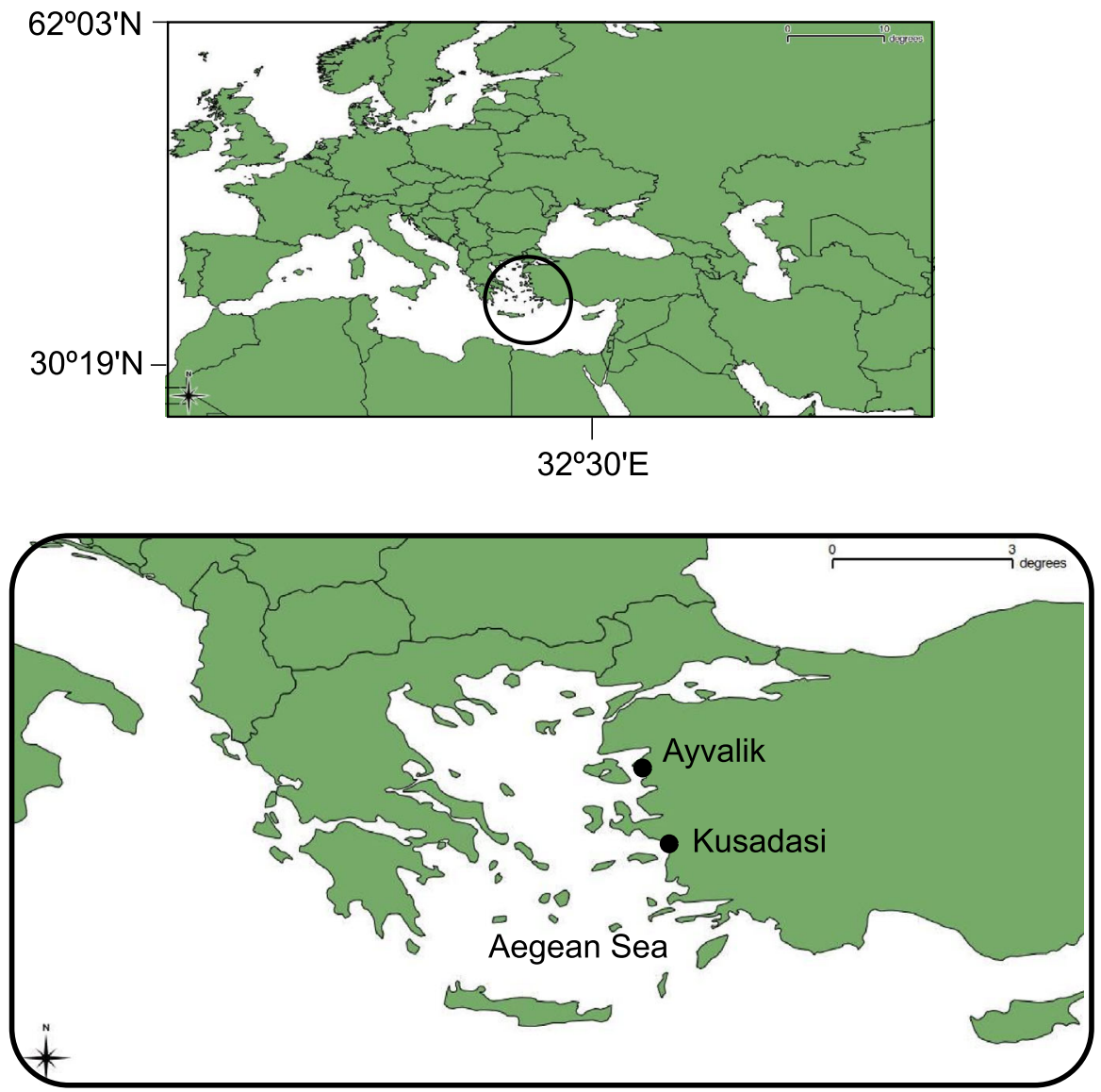

before the opening of the sea cucumber fishery (September 2012).

Alive specimens of $H$. polii and H. tubulosa were transferred to the laboratory in sea water and under refrigerated conditions. We registered the total length $(\mathrm{EL} \pm 0.01 \mathrm{~cm})$ and eviscerated weight $(\mathrm{EW} \pm 0.01 \mathrm{~g})$ for each individual. The eviscerated length and weight were registered on 100 individuals for each species $(H$. polii and H. tubulosa). For each specimen, a sample of the internal longitudinal muscle bands or body wall was taken and preserved in absolute ethanol for genetic analysis.

\section{Biometry analysis}

The size classes (EL) for each species and locality were represented using bar graphics. Differences in length and weight parameters among fishery and nonfishery localities for each target species were tested by ANOVA considering the "locality" as factor. These analyses were performed in R statistical software ( $R$
Development Core Team, 2010), using “ade4" (Chessel, 1992) and "mgcv" (Wood, 2006) packages.

Genetic analysis

According previous genetic studies carried out on sea cucumbers (Vergara-Chen et al., 2010; Borrero-Pérez et al., 2011; González-Wangüemert \& Borrero-Pérez, 2012; Valente et al., 2014), a representative number of individuals from each locality were analyzed. DNA extractions were done based on Sambrook et al. (1989) protocol. Dilutions from DNA extractions varied between 1:100 to 1:400 based on their concentration and cleanliness. Fragments of the mitochondrial genes cytochrome oxidase I (COI) and 16S rRNA were amplified by the polymerase chain reaction (PCR) using the following primers: COIceF $5^{\prime}$-ACTGCCCACGCCCTAGTAATGATATTT- ${ }^{\prime}$ and COIceR $5^{\prime}$ TCGTGTGTCTACGTCCATTCCTACTGT-3', specifics for echinoderms (Hoareau \& Boissin, 2010; 16Sar-L 5'-CGCCTGTTTATCAAAAACAT-3' and 
16SB 5'-CTCCGGTTTGAACTCAGATCA-3', universal primers for invertebrates (Palumbi, 1996). For both genes, PCR reactions were carried out in $25 \mu \mathrm{l}$ volume reaction containing $2.5 \mu \mathrm{l}$ amplification buffer $(10 \times), 2.5 \mu \mathrm{l}$ of each primer (forward and reverse) $(10 \mathrm{mM}), 1.0 \mu \mathrm{l}$ of $\mathrm{MgCl}_{2}(50 \mathrm{mM}), 0.2 \mu \mathrm{l}$ of dNTP $\operatorname{mix}(25 \mathrm{mM}), 0.5 \mu \mathrm{l}$ of $1 \mathrm{U}$ Taq polymerase, and $1 \mu \mathrm{l}$ of DNA diluted.

For COI, amplification proceed with an initial denaturation temperature at $95^{\circ} \mathrm{C}$ for $3 \mathrm{~min}$, then 40 cycles of denaturation at $94^{\circ} \mathrm{C}$ for $4 \mathrm{~s}$, annealing to $45^{\circ} \mathrm{C}$ for $1 \mathrm{~min} 10 \mathrm{~s}$ and extension at $72^{\circ} \mathrm{C}$ for $1 \mathrm{~min}$ $10 \mathrm{~s}$ followed by a final extension at $72^{\circ} \mathrm{C}$ for $5 \mathrm{~min}$. For $16 \mathrm{~S}$, amplification proceed with an initial denaturation temperature at $95^{\circ} \mathrm{C}$ for $3 \mathrm{~min}$, then 40 cycles of denaturation at $94^{\circ} \mathrm{C}$ for $20 \mathrm{~s}$, annealing to $45^{\circ} \mathrm{C}$ for $20 \mathrm{~s}$, and extension at $72^{\circ} \mathrm{C}$ for $20 \mathrm{~s}$ followed by a final extension at $72^{\circ} \mathrm{C}$ for $10 \mathrm{~min}$. A 4- $\mu \mathrm{l}$ sample of each PCR product together with $3 \mu$ of Green GoTaq ${ }^{\circledR}$ reaction buffer was run on $1.5 \%$ agarose gel and stained with GelRed ${ }^{\mathrm{TM}}$.

DNA fragments were sequenced by the molecular biology service at CCMAR facilities (http://www. ccmar.ualg.pt/, Faro, Portugal) in an ABI Prism 3130 automated genetic analyzer (Applied Biosystems).

Sequences were fixed using FinchTV (v.1.4.0) and aligned using muscle alignment method (v.3.5; Edgar, 2004) implemented in Seaview software (v.4.3.1) and revised manually later. Haplotype $(H)$ and nucleotide $(\pi)$ diversities, total number of haplotypes, exclusive haplotypes, and polymorphic sites as descriptors of the genetic diversity were calculated for each sample using ARLEQUIN software (v.3.5.1.3).

\section{Results}

Biometry

A total of 200 sea cucumbers belonging to the two target species (50 individuals per locality and per species) were collected and measured. Holothuria polii eviscerated individuals ranged in length from 8 to $13 \mathrm{~cm}$ in Ayvalik (fishery area), and from 9 to $17 \mathrm{~cm}$ in Kusadasi (non-fishery area), showing both localities a unimodal frequency distribution (Fig. 2). Holothuria tubulosa showed a multimodal distribution in both areas, ranging in length from 10 to $23 \mathrm{~cm}$ (EL) (Fig. 2). Individuals from Ayvalik showed lower weight than specimens from Kusadasi considering both species (Fig. 2).

The eviscerated length and weight of the different species were also analyzed in each locality (Table 1; Fig. 3). The ANOVA performed on the fishery and non-fishery localities detected significant differences for the length in $H$. polii showing the larger individuals in Kusadasi (non-fishery area) (Table 1). Considering the eviscerated weight, the ANOVA showed significant differences for the two species, finding the heaviest individuals of $H$. polii and $H$. tubulosa in Kusadasi (Table 1; Fig. 3).

\section{Genetics}

Analysis of COI sequences 517 bp in length from 42 individuals of Holothuria polii from Ayvalik and Kusadasi showed 23 different haplotypes (GENBANK codes: KJ493888, KJ49389, KJ493895, KJ493899, KJ493900, KJ493897, KJ493902, KJ493897, KJ493894, KJ493889, KJ493898, KJ493893, KJ493892, KJ493896, KJ812189KJ812197), of which 7 were shared among both localities and the other ones were exclusive haplotypes for Kusadasi (10) and Ayvalik (6) (Table 2). We found the highest genetic diversity (total number of haplotypes, number of exclusive haplotypes, polymorphic sites, haplotype and nucleotide diversities) in Kusadasi, where sea cucumber fishery is not allowed (Table 2). When analyzed the $16 \mathrm{~S}$ gene for the same individuals, sequences of $432 \mathrm{bp}$ were obtained and 16 haplotypes found (GENBANK codes: KJ408308, KJ408306, KJ408307, KJ408280, KJ408289, KJ812154-KJ812164). Four haplotypes were shared between localities and 6 exclusive haplotypes per locality were registered (Table 2). For this gene, Kusadasi showed again the highest genetic diversity considering the values of polymorphic sites, haplotype and nucleotide diversity.

The analysis of COI region in 35 individuals of Holothuria tubulosa allowed to obtain sequences 592 bp in length, describing 23 haplotypes (GENBANK codes: KJ719531-KJ719553), only two shared between localities (Table 2). For this species, the haplotype diversity was only higher in Kusadasi sample, with similar values for the other diversity parameters in both sampling sites. Analysis of 16S sequences 467 bp in length from 45 individuals of $H$. tubulosa detected 14 haplotypes (GENBANK codes: KJ812175-KJ812188), 4 of them also shared between localities. Ayvalik locality showed the highest values of genetic diversity, considering all parameters except 


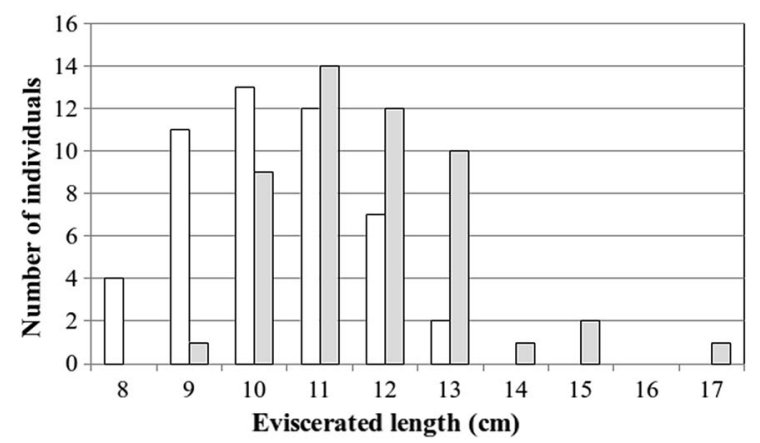

Holothuria polii

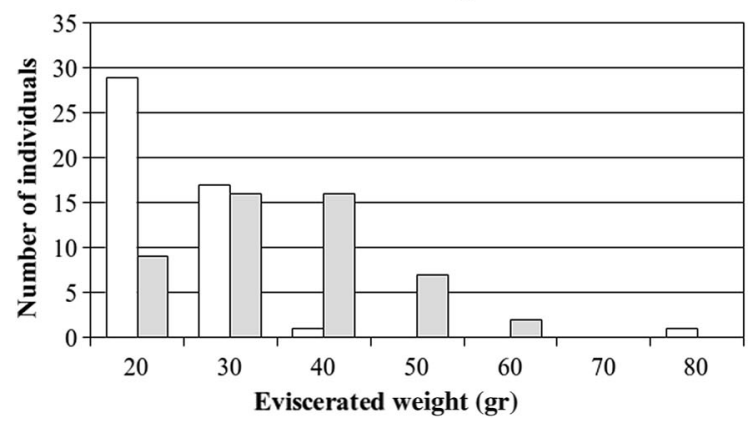

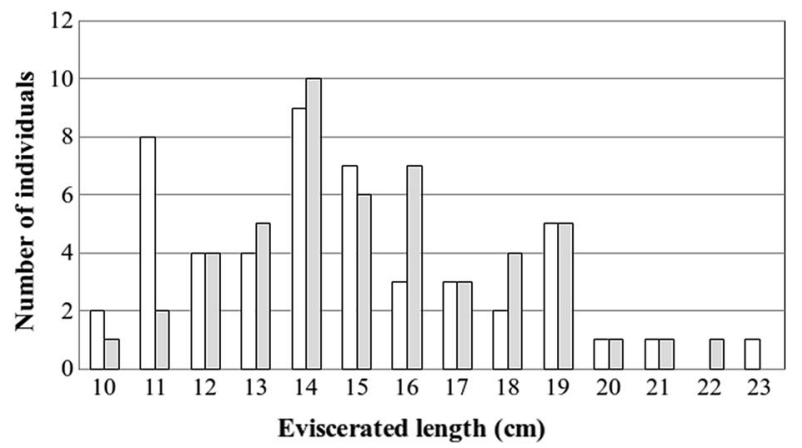

Holothuria tubulosa

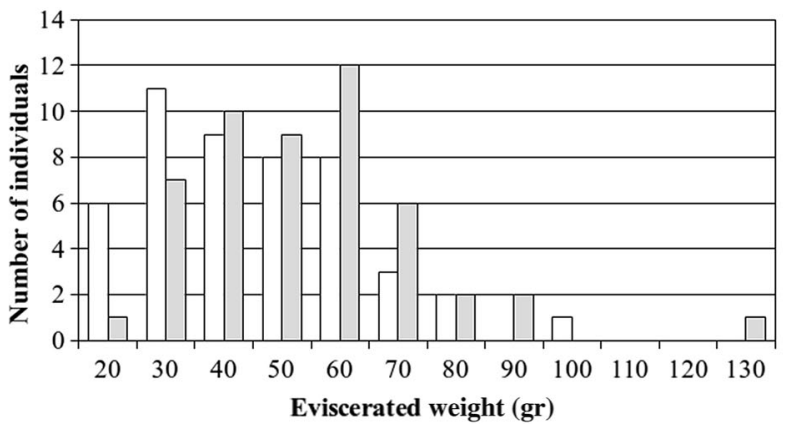

Fig. 2 Length (above) and weight (below) frequency distributions of our target species (Holothuria polii and H. tubulosa) in fishery (Ayvalik; white bars) and non-fishery areas (Kusadasi; gray bars) from Turkey

Table 1 ANOVA table for variables considered in the study of the two target species (H. polii and H. tubulosa)

\begin{tabular}{lllll}
\hline Variable & Sum-of-squares & df & $F$-ratio & $P$ \\
\hline Length & & & & \\
$\quad$ H. polii & 60.996 & 1 & 32.182 & $1.423 \mathrm{e}-07 * * *$ \\
$\quad$ H. tubulosa & 11.63 & 1 & 1.412 & 0.2376 \\
Weight & & & & \\
H. polii & 2777.3 & 1 & 31.552 & $1.819 \mathrm{e}-07 * * *$ \\
H. tubulosa & 2737 & 1 & 7.2988 & $0.008132^{* *}$ \\
\hline$* p<0.05 ; * * 0.01<p<0.05 ; * * *$ & $0.001<p<0.01$
\end{tabular}

for nucleotide diversity which was higher in Kusadasi (Table 2).

\section{Discussion}

Biometry and reproduction

Life-history theory and experimental studies predict that the fishery selective mortality will lead to slower growth, higher reproductive investment and maturation at younger ages (Law, 2007; Walsh \& Reznick,
2008). Most fisheries target large individuals, so that fisheries-induced mortality is highly size selective with important repercussions for the sustainability of the resources (Kuparinenn \& Merila, 2007; Audzijonyte et al., 2012).

As it was explained previously, sea cucumber fisheries are increasing in the Mediterranean Sea with very important catches (around 600 tonnes/year in 2011), which are focused mainly on Turkish waters (Aydin, 2008; González-Wangüemert et al., 2014). However, no evaluation about the effects of that fishery on the Mediterranean species has been carried out until now. Results obtained from this study, demonstrated the lost of the larger size classes on an exploited population of $H$. polii and a significant reduction of its length and weight. Those effects, larger, and heavier individuals in Kusadasi (nonfishery area), were also found on $\mathrm{H}$. tubulosa although only the weight differences among protected and nonprotected areas were significant. The effects of the fishery could be more important and evident on $H$. polii because around $80 \%$ of the sea cucumbers caught in Turkey belong to this species, and only $20 \%$ to $H$. 
Holothuria polii

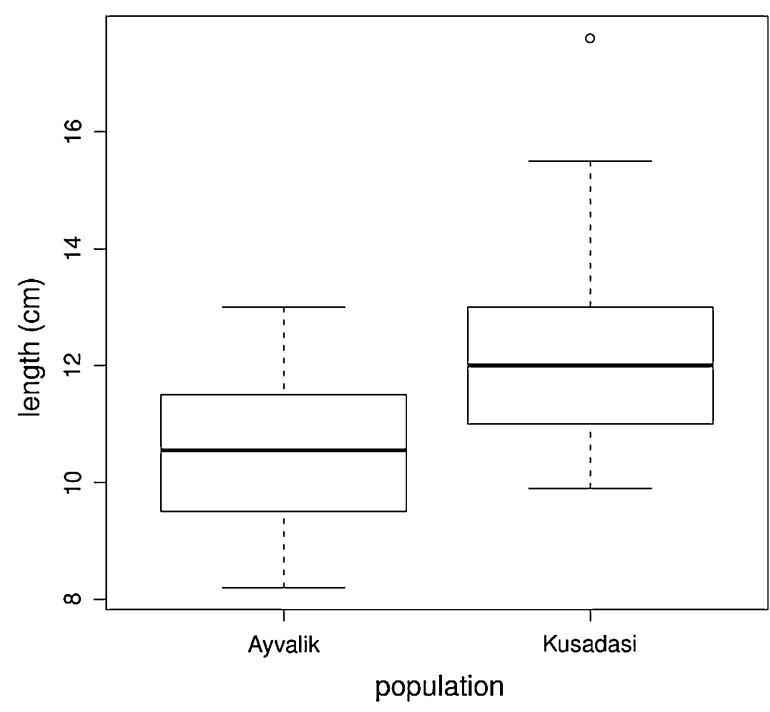

Holothuria tubulosa

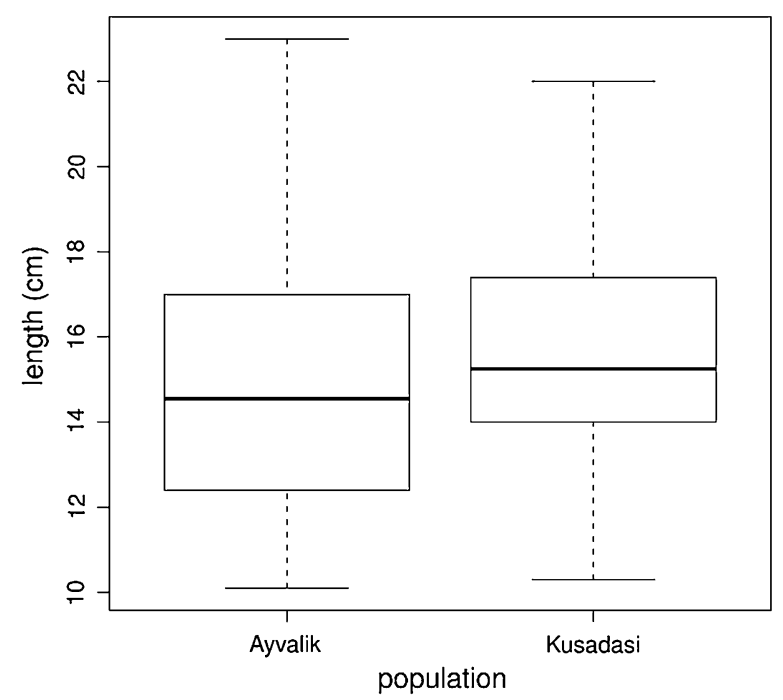

Holothuria polii

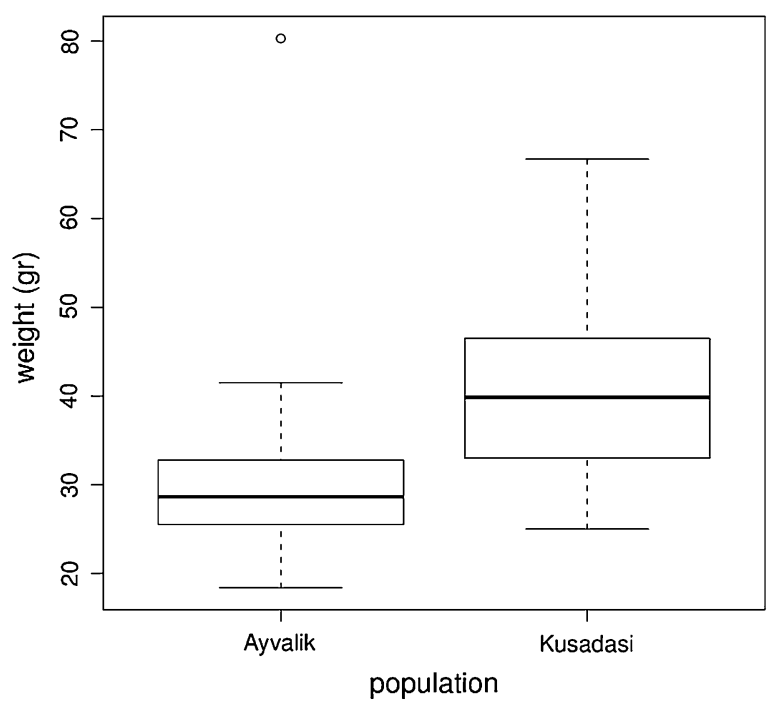

Holothuria tubulosa

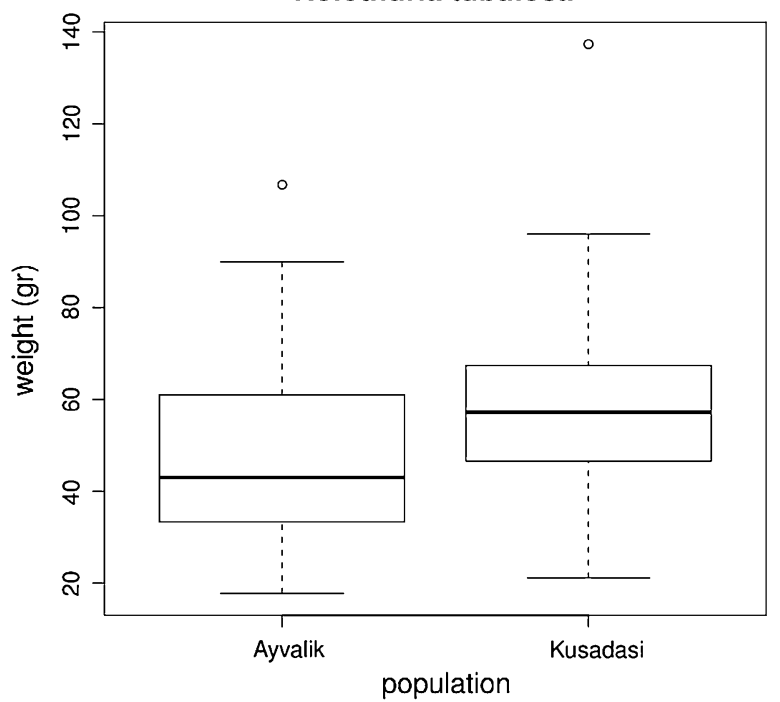

Fig. 3 Mean length and weight in the different sampled populations per each target species (ANOVA analysis)

tubulosa plus H. mammata (González-Wangüemert et al., 2014; Dr. Mehmet per. Com.). These differences on the catches for each species could be due to a higher density of $H$. polii on Turkish waters. However, other reasons such as the preferences of the Asian market for this species or its gregarious behavior in shallow waters which facilitates the collection, could justify those observations too. Mezali et al. (2006) carried out a study on $H$. tubulosa and $H$. polii inhabiting Posidonia oceanica meadows from Algerian waters, finding higher density for the first species. In the present study, any sampling in Turkish waters was done on $P$. oceanica meadows. Therefore, density differences found among regions could be affected by the habitat rather than the geographical area.

The observed changes in the adult body sizes could be also changing predator-prey interactions, mainly because new predator species could take advantage of the length/weight reduction in fishery areas, considering them an achievable food resource (Kuparinenn \& Merila, 2007). Although, we were not able to test this hypothesis with the data available, further studies 
Table 2 Molecular diversity measures for populations of Holothuria polii and H. tubulosa

\begin{tabular}{lllllll}
\hline $\begin{array}{l}\text { Region/ } \\
\text { species }\end{array}$ & Localities & $N$ & $\begin{array}{l}\mathrm{Nh} \\
(\mathrm{exc})\end{array}$ & $S$ & $H$ & $\pi$ \\
\hline
\end{tabular}

COI

H. polii

$\begin{array}{llllll}\text { Ayvalik } & 20 & 13(6) & 19 & 0.9105 & 0.0050 \\ \text { Kusadasi } & 22 & 17(10) & 25 & 0.9697 & 0.0060\end{array}$

H. tubulosa

$\begin{array}{llllll}\text { Ayvalik } & 19 & 13(11) & 31 & 0.8772 & 0.0151 \\ \text { Kusadasi } & 16 & 12(10) & 28 & 0.9167 & 0.0104\end{array}$

$16 \mathrm{~S}$

H. polii

$\begin{array}{llllll}\text { Ayvalik } & 20 & 10(6) & 10 & 0.7105 & 0.0020 \\ \text { Kusadasi } & 22 & 10(6) & 14 & 0.7489 & 0.0030\end{array}$

H. tubulosa

\begin{tabular}{lrrrrr} 
Ayvalik & 21 & $10(5)$ & 32 & 0.8619 & 0.0095 \\
Kusadasi & 24 & $8(4)$ & 28 & 0.7428 & 0.0103 \\
\hline
\end{tabular}

$N$ number of individuals, $N h$ number of haplotypes (exclusive), $S$ polymorphic sites, $H$ haplotype diversity, $\pi$ nucleotide diversity

should try to address this potential fishery effect on Turkish populations.

Because of the positive correlation between body size and fecundity in sea cucumbers (Kazanidis et al., 2014), a reduction in the age at maturation could be also expected as a consequence of the fisheries, ultimately reducing the age-specific sizes of adult individuals and the reproductive potential of the population such as it has been demonstrated in fish previously (Neuheimer \& Taggart, 2010; Chuwen et al., 2011 and references therein). Furthermore, if a reduced average body size is not compensated by an increase of the population abundance, which is highly unlikely in sea cucumbers considering their low effective recruitment, the biomass and yield of the stock should decrease too (Audzijonyte et al., 2012). This fact could be happening in some sea cucumber stocks from Northern Turkey due to the increase of their catches in the last years favored by a higher economical value and growing foreign demand (Aydin, 2008; González-Wangüemert et al., 2014). In fact, MoFAL (Ministry of Food, Agriculture and Livestock, Turkey), due to the reduction of the stocks and low profitability of their fisheries in the northern area (lower number of individuals per effort unit and smaller specimens), forbidden the sea cucumber fishery in this zone since September 2012 and opened the South region previously protected (GonzálezWangüemert et al., 2014).

Genetic diversity and effects of MPAs

Marine protected areas (MPAs) on high-value species of sea cucumbers have demonstrated very beneficial effects for protection (Cariglia et al., 2013): (1) the probability of observing holothurians in protected areas $(\sim 80 \%)$ was twice that in areas subjected to fishing; (2) the probability of observing holothurians of high or medium commercial value was 10 -fold greater inside rather than outside MPAs; (3) MPAs helped to conserve high densities of holothurians with economic importance. Previously, similar results were also registered in Mayotte reefs (Western Indian Ocean), a protected area without sea cucumber fisheries (Eriksson et al., 2012b). A recent study reviewing a high number of MPAs from New Zealand and considering fishes and macro-invertebrates concluded that MPAs are also reference sites for conserving natural genetic and population structure (Costello, 2014).

'No-take' marine protected areas are an important tool to manage coastal fisheries, which could prevent the collapse of stocks (Sale et al., 2005; Teske et al., 2010). Primary considerations when designating MPAs are the conservation of biodiversity and the maintenance of ecosystem functioning. Another subjects such as connectivity between MPAs and conservation of genetic diversity, should be also important aspects for designing, but those are rarely considered (Roberts et al., 2003). Scarce information has been published about the "genetic effects" of fishery protection, and any data is available for sea cucumbers under this topic. Pérez-Ruzafa et al. (2006) working on white seabream (Diplodus sargus) demonstrated that non-fishery populations had significantly higher total and standard allelic richness than fishery ones. The three MPAs considered in that work, provided 97.3\% of the total number of alleles found in all the Western Mediterranean populations of D. sargus and $9.5 \%$ of this area's genetic pool is shut away from those marine reserves. Considering these results, authors also concluded that fish sanctuaries act as reservoirs for rare alleles, thus precluding their extinction. Similar conclusions, with higher genetic diversity in MPAs, were obtained for another fish target species (Mullus 
surmuletus and M. barbatus) (Félix-Hackradt et al., 2013).

Our results describe a similar pattern, especially on $H$. polii which shows the highest genetic diversity (COI and 16S genes) in the protected area (Kusadasi). This pattern showing higher genetic diversity on the protected population is also observed on $H$. tubulosa species considering the haplotype (COI) and nucleotide (16S) diversity. The differences on the genetic patterns observed among species, could be explained considering the specific percentage of the catches (González-Wangüemert et al., 2014), being much higher on $\mathrm{H}$. polii $(80 \%)$ and therefore showing more evident effects on this species.

Previous works on sea cucumber population genetics also corroborate our findings. Turkish localities under fishery pressure such as Foça (H. mammata) and Ayvalik (H. tubulosa), showed very low genetic diversity compared with other localities sampled in the Atlantic Ocean (only H. mammata) and Mediterranean Sea (H. mammata and H. tubulosa) (BorreroPérez, 2010; Borrero-Pérez et al., 2011). A recent genetic study on $H$. polii established the highest genetic diversity of this species in Kusadasi (Valente et al., 2014). A gradient of genetic diversity can be described from Eastern to Western Mediterranean Sea, locating the origin of $H$. polii in Turkish waters. This assertion is justified because of the oldest expansion time and the highest genetic diversity of all studied localities (number of total and exclusive haplotypes, polymorphisms, haplotype and nucleotide diversity) were observed in Kusadasi (Turkey).

The higher genetic diversity in the protected area could be crucial to the survival of sea cucumbers species. The high number of exclusive haplotypes showed in Kusadasi area may increase their fitness under unusual conditions (Ryman et al., 1995; Pérez-Ruzafa et al., 2006; Vergara-Chen et al., 2010; González-Wangüemert et al., 2012; GonzálezWangüemert \& Vergara-Chen, 2014). That genetic diversity could provide the raw material for the maintenance of the diversity longer evolutionary time-scales and may also confer the basis for adaptation to environmental change (Sanford \& Kelly, 2011; González-Wangüemert \& Pérez-Ruzafa, 2012; González-Wangüemert \& Vergara-Chen, 2014).

\section{Conclusions and conservation implications}

Considering our results, fishery pressure could be reducing the size of the individuals and decreasing the genetic diversity of sea cucumber stocks along Turkish coastal areas. MoFAL should control the number of vessels with permissions to work on the fishery area, as well as illegal catches (such as they were previously registered, González-Wangüemert et al., 2014) and vessels could be penalized. The current fishery effort in Turkey is extremely heavy ranged from 720,000 to 1,080,000 sea cucumbers per day (González-Wangüemert et al., 2014), mainly focused on $H$. polii. Therefore, a reduction of the number of vessels catching sea cucumbers or the number the hours working during the day should be implemented in the fishery areas.

Kusadasi was showing healthy sea cucumber populations (H. polii and H. tubulosa) as result of the fishery protection. However, the changes that follow its recent opening (September 2012) to the sea cucumber fishery, should be evaluated.

In fact, MPAs could be established in places with pristine sea cucumber populations (MPAs network) mainly for $H$. polii, the most important target species. Those zones could protect primary breeding grounds favoring the recruitment and biomass exportation on close fishery areas. Also, some restricted zones in those MPAs could support traditional fisheries, although the use of hookah fishery should be forbidden. Likely, this MPAs network would favor a better management of the sea cucumber fisheries in Turkey, conserving the genetic diversity of the species too.

Acknowledgments This research was supported by CUMFISH project (PTDC/MAR/119363/2010; http://www. ccmar.ualg.pt/cumfish/) funded by Fundacão para Ciência e Tecnologia (Portugal). M. González-Wangüemert was supported by a FCT postdoctoral fellowship (SFRH/BPD/70689/ 2010) and S. Valente by a FCT research fellow (CCMAR/BI/ 0023/2012). Special thanks to Silo Tarım company for their help during samplings, and Ozan Sen and Catarina Antunes for their collaboration on the lab work.

\section{References}

Anderson, S. C., J. M. Flemming, R. Watson \& H. K. Lotze, 2011. Serial exploitation of global sea cucumber fisheries. Fish and Fisheries 12: 317-339. 
Audzijonyte, A., A. Kuparinen \& E. Fulton, 2012. How fast is fisheries-induced evolution? Quantitative analysis of modelling and empirical studies. Evolutionary Applications. doi:10.1111/eva.12044.

Aydın, M., 2008. The commercial sea cucumbers fishery in Turkey. SPC Beche-de-Mer Information Bulletin 28: $40-43$.

Aydın, M., H. Sevgili, B. Tufan, Y. Emre \& S. Köse, 2011. Proximate composition and fatty acid profile of three different fresh and dried commercial sea cucumbers from Turkey. International Journal of Food Science and Technology 46: 500-508.

Borrero-Pérez, G., 2010. Sistemática y filogeografía de las especies del subgénero Holothuria (Echinodermata: Holothuriidae: Holothuria) de la región Atlanto-Mediterránea. Universidad de Murcia, Murcia.

Borrero-Pérez, G., M. González-Wangüemert, A. Pérez-Ruzafa \& C. Marcos, 2011. Phylogeography of the Atlanto-Mediterranean sea cucumber Holothuria (Holothuria) mammata: the combined effects of historical processes and current oceanographical pattern. Molecular Ecology 20: 1964-1975.

Cariglia, A., S. K. Wilson, N. Graham, R. Fisher, J. Robinson, R. Aumeeruddy, R. Quatre \& N. Polunin, 2013. Sea cucumbers in the Seychelles: effects of marine protected areas on high-value species. Aquatic Conservation: Marine and Freshwater Ecosystems 23: 418-428.

Chessel, D., 1992. The ade4 package-I: one-table methods. R News 4: 5-10.

Chuwen, B. M., I. C. Potter, N. G. Hall, S. D. Hoeksema \& L. J. Laurenson, 2011. Changes in catch rates and length and age at maturity, but not growth, of an estuarine plotosid (Cnidoglanis macrocephalus) after heavy fishing. Fishery Bulletin 109: 247-260.

Conand, C., 1989. Les Holothuries Aspidochirotes du lagon de Nouvelle-Calédonie: biologie, écologie et exploitation. Etudes et Thèses, O.R.S.T.O.M., Paris: 393 pp.

Conand, C., 1990. The fishery resources of Pacific island countries. Part 2: Holothurians. FAO Fisheries Technical Paper, No. 272.2. FAO, Rome.

Conand, C., 2004. Present status of world sea cucumber resources and utilisation: An international overview. In Lovatelli, A., C. Conand, S. Purcell, S. Uthicke, J. F. Hamel \& A. Mercier (eds), Advances in Sea Cucumber Aquaculture and Management. FAO Fisheries Technical Paper, No. 463. FAO, Rome: 13-24.

Conand, C., 2008. Population status, fisheries and trade of sea cucumbers in Africa and the Indian Ocean. In ToralGranda, V., A. Lovatelli \& M. Vasconcellos (eds), Sea Cucumbers: A Global Review of Fisheries and Trade. FAO Fisheries and Aquaculture Technical Paper, No. 516, Vol. 516. FAO, Rome: 143-193.

Conand, C. \& M. Byrne, 1993. A review of recent developments in the world sea cucumber fisheries. Marine Fisheries Review 55: 1-13.

Costello, M. J., 2014. Long live Marine Reserves: a review of experiences and benefits. Biological Conservation 176: 289-296.

Coulon, P. \& M. Jangoux, 1993. Feeding rate and sediment reworking by the holothuroid Holothuria tubulosa (Echinodermata) in a Mediterranean seagrass bed off Ischia Island, Italy. Marine Ecology Progress Series 92: 201-204.
Edgar, R. C., 2004. MUSCLE: multiple sequence alignment with high accuracy and high throughput. Nucleic Acids Research 32(5): 1792-1797.

Eriksson, H., M. Torre Castro \& P. Olsson, 2012a. Mobility, expansion and management of a multi-species scuba diving fishery in East Africa. PLoS One 7: e35504.

Eriksson, H. M., M. Byrne \& M. de la Torre-Castro, 2012b. Sea cucumber (Aspidochirotida) community, distribution and habitat utilization on the reefs of Mayotte, Western Indian Ocean. Marine Ecology Progress Series 452: 159-170.

Félix-Hackradt, F., C. W. Hackradt, A. Pérez-Ruzafa \& J. A. García-Charton, 2013. Discordant patterns of genetic connectivity between two sympatric species, Mullus barbatus (Linnaeus, 1758) and Mullus surmuletus (Linnaeus, 1758), in south-western Mediterranean Sea. Marine Environmental Research 92: 23-34.

González-Wangüemert, M. \& G. Borrero-Pérez, 2012. A new record of Holothuria arguinensis colonizing the Mediterranean Sea. Marine Biodiversity Records 5: e105.

González-Wangüemert, M. \& A. Pérez-Ruzafa, 2012. In two waters: contemporary evolution of lagoonal and marine white seabream populations. Marine Ecology 33: 337-349.

González-Wangüemert, M. \& C. Vergara-Chen, 2014. Environmental variables, habitat discontinuity and life history shaping the genetic structure of Pomatoschistus marmoratus. Helgoland Marine Research 68: 357-371.

González-Wangüemert, M., T. Vega-Fernández, A. Pérez-Ruzafa, V. M. Giacalone \& F. Badalamenti, 2012. Genetic impact of a restocking experiment of white seabream in Sicily (Northwestern Mediterranean Sea). Journal of Sea Research 68: 41-48.

González-Wangüemert, M., C. Conand, S. Uthicke, G. BorreroPérez, M. Aydin, K. Erzini \& E. Serrão, 2013a. Sea cucumbers: the new resource for a hungry fishery (CUMFISH). SPC Beche-de-Mer Information Bulletin 33: 65-66.

González-Wangüemert, M., T. Braga, M. Silva, S. Valente, F. Rodrigues \& E. Serrão, 2013b. Volunteer programme assesses the Holothuria arguinensis populations in Ria Formosa (southern Portugal). SPC Beche-de-Mer Information Bulletin 33: 44-48.

González-Wangüemert, M., M. Aydin \& C. Chantal, 2014. Assessment of target sea cucumber populations from Aegean Sea (Turkey): first insights for a right management of their fisheries. Ocean \& Coastal Management 92: 87-94.

Hamel, J. H. \& A. Mercier, 2008. Population status, fisheries and trade of sea cucumbers in temperate areas of the Northern Hemisphere. In Toral-Granda, V., A. Lovatelli \& M. Vasconcellos (eds), Sea cucumbers. A global review on fishery and trade. FAO Fisheries Technical Paper No. 516. FAO, Rome.

Hoareau, T. B. \& E. Boissin, 2010. Design of phylum-specific hybrid primers for DNA bar coding: addressinzg the need for efficient COI amplification in the Echinodermata. Molecular Ecology Resources 10: 960-967.

Kazanidis, G., C. Antoniadou, A. P. Lolas, N. Neofitou, D. Vafidis, C. Chintiroglou \& C. Neofitou, 2010. Population dynamics and reproduction of Holothuria tubulosa (Holothuroidea: Echinodermata) in the Aegean Sea. Journal of the Marine Biological Association of the United Kingdom 90: 895-901. 
Kazanidis, G., A. Lolas, D. Vafidis, 2014. Reproductive cycle of the traditionally exploited sea cucumber Holothuria tubulosa (Holothuroidea: Aspidochirotida) in Pagasitikos Gulf, western Aegean Sea, Greece. Turkish Journal of Zoology 38. doi:10.3906/zoo-1302-31.

Kuparinenn, A. \& J. Merila, 2007. Detecting and managing fisheries- induced evolution. Trends in Ecology and Evolution 22: 652-659.

Law, R., 2007. Fisheries-induced evolution: present status and future directions. Marine Ecology-Progress Series 335: 271-277.

Lovatelli, A., C. Conand, S. Purcell, S. Uthicke, J.-F. Hamel \& A. Mercier, 2004. Advances in Sea Cucumber Aquaculture and Management. FAO Fisheries Technical Paper No. 463. FAO, Rome.

Maillaud, C., 1999. Diving accidents related to sea cucumber fishing in Nose Be, Madagascar. SPC Beche-de-Mer Information Bulletin 11: 23-25.

Mezali, K., V. Zupo \& P. Francour, 2006. Population dynamics of Holothuria (Holothuria) tubulosa and Holothuria (Lessonothuria) polii of an Algerian Posidonia oceanica meadow. Biologia Marina Mediterranea 13: 158-161.

Neuheimer, A. B. \& C. T. Taggart, 2010. Can changes in lengthat-age and maturation timing in Scotian Shelf haddock (Melanogrammus aeglefinus) be explained by fishing? Canadian Journal of Fisheries and Aquatic Sciences 67: 854-865.

Palumbi, S. R., 1996. Nucleic Acids II: The Polymerase Chain Reaction. Molecular Systematics. Sinauer Associates, Sunderland, MA.

Pérez-Ruzafa, Á., M. González-Wangüemert, P. Lenfant, C. Marcos \& J. A. García-Charton, 2006. Effects of fishing protection on the genetic structure of fish populations. Biological Conservation 129: 244-255.

Purcell, S., 2010. Managing Sea Cucumber Fisheries with an Ecosystem Approach. FAO Fisheries and Aquaculture Technical Paper No. 520. FAO, Rome.

Purcell, S. W., 2014. Value, market preferences and trade of beche-de-mer from pacific Island sea cucumbers. PLoS One 9: e95075.

Purcell, S. W., A. Mercier, C. Conand, J. F. Hanel, V. ToralGranda, A. Lovatelli \& S. Uthicke, 2013. Sea cucumber fisheries: global analysis of stocks, management measures and drivers of overfishing. Fish and Fisheries 14: 34-59.

R Development Core Team., 2010. R: A Language and Environment for Statistical Computing. R Foundation for Statistical Computing, Vienna.

Roberts, C. M., S. Andelman, G. Branch, R. H. Bustamante, J. C. Castilla, J. Dugan, B. S. Halpern, K. D. LaVerty, H.
Leslie, J. Lubchenco, D. McArdle, H. P. Possingham, M. Ruckelshaus \& R. R. Warner, 2003. Ecological criteria for evaluating candidate sites for marine reserves. Ecological Applications 13: S199-S214.

Ruffez, J., 2008. Diving for holothurians in Vietnam: A human and environmental disaster. SPC Beche-de-Mer Information Bulletin 28: 42-45.

Ryman, N., F. Utter \& L. Laikre, 1995. Protection of intraspecific biodiversity of exploited fishes. Reviews in Fish Biology and Fisheries 5: 417-446.

Sale, P. F., R. K. Cowen, B. S. Danilowicz, G. P. Jones, J. P. Kritzer, K. C. Lindeman, S. Planes, N. V. C. Polunin, G. T. Russ, Y. V. Sadovy \& R. S. Steneck, 2005. Critical science gaps impede use of no-take fishery reserves. Trends in Ecology and Evolution 20: 74-80.

Sambrook, J., E. F. Fritsch \& T. Maniatis, 1989. Molecular Cloning. Cold Spring Harbor Press, New York.

Sanford, E. \& M. Kelly, 2011. Local adaptation in marine invertebrate. Annual Review of Marine Science 3: 509-535.

Teske, P. R., F. R. G. Forget, P. D. Cowley, S. von der Heyden \& L. B. Beheregaray, 2010. Connectivity between marine reserves and exploited areas in the philopatric reef fish Chrysoblephus laticeps (Teleostei: Sparidae). Marine Biology 157: 2029-2042.

Toral-Granda, V., A. Lovatelli \& M. Vasconcellos, 2008. Sea Cucumbers. A Global Review on Fishery and Trade. FAO Fisheries Technical Paper. No. 516. FAO, Rome.

Uthicke, S., D. Welch \& J. A. H. Benzie, 2004. Slow growth and lack of recovery in overfished holothurians on the Great Barrier Reef: evidence from DNA fingerprints and repeated large-scale surveys. Conservation Biology 18: 1395-1404.

Valente, S., E. Serrão \& M. González-Wangüemert, 2014. West vs East Mediterranean Sea: origin and genetic differentiation of the sea cucumber Holothuria polii. Marine Ecology. doi:10.1111/maec.12156.

Vergara-Chen, C., M. González-Wangüemert, C. Marcos \& A. Pérez-Ruzafa, 2010. Genetic diversity and connectivity remain high in Holothuria polii (Delle Chiaje 1823) across a coastal lagoon-open sea environmental gradient. Genetica 138: 895-906.

Walsh, M. R. \& D. N. Reznick, 2008. Interactions between the direct and indirect effects of predators determine life history evolution in a killifish. Proceedings of the National Academy of Sciences of the United States of America 105: 594-599.

Wood, S., 2006. Generalized Additive Models: An Introduction with R. Chapman and Hall, London. 